\title{
Atlantis
}

Critical Studies in Gender, Culture \& Social Justice

Études critiques sur le genre, la culture, et la justice

\section{Toppled Monuments and Black Lives Matter: Race, Gender, and Decolonization in the Public Space. An Interview with Charmaine A. Nelson}

\section{Christiana Abraham}

Volume 42, Number 1, 2021

"Covid and the Academy" \& Open-themed Research

URI: https://id.erudit.org/iderudit/1082012ar

DOI: https://doi.org/10.7202/1082012ar

See table of contents

Publisher(s)

Mount Saint Vincent University

ISSN

1715-0698 (digital)

Explore this journal

Cite this article

Abraham, C. (2021). Toppled Monuments and Black Lives Matter: Race, Gender, and Decolonization in the Public Space. An Interview with Charmaine A.

Nelson. Atlantis, 42(1), 1-17. https://doi.org/10.7202/1082012ar

\section{Article abstract}

This paper discusses the recent backlash against public monuments spurred by Black Lives Matter (BLM) protests in North America and elsewhere following the killing by police of George Floyd, an unarmed African-American man in the United States. Since this event, protestors have taken to the streets to bring attention to police brutality, systemic racism, and racial injustice faced by Black and Indigenous people and people of colour in the United States, Canada, Great Britain and some European countries. In many of these protests, outraged citizens have torn down, toppled, or defaced monuments of well-known historic figures associated with colonialism, slavery, racism, and imperialism. Protestors have been demanding the removal of statues and monuments that symbolize slavery, colonial power, and systemic and historical racism. What makes these monuments problematic and what drives these deliberate and spectacular acts of defiance against these omnipresent monuments? Featuring an interview with art historian Charmaine A. Nelson, this article explores the meanings of these forceful, decolonial articulations at this moment. The interview addresses some complex questions related to monumentalization and the public sphere, symbolism and racial in/justice. In so doing, it suggests that monuments of the future need to be reimagined and redefined contemporaneously with shifting social knowledge and generational change.
This document is protected by copyright law. Use of the services of Erudit (including reproduction) is subject to its terms and conditions, which can be viewed online. 


\title{
Toppled Monuments and Black Lives Matter: Race, Gender, and Decolonization in the Public Space. An Interview with Charmaine A. Nelson
}

\author{
by Christiana Abraham
}

\begin{abstract}
This paper discusses the recent backlash against public monuments spurred by Black Lives Matter (BLM) protests in North America and elsewhere following the killing by police of George Floyd, an unarmed African-American man in the United States. Since this event, protestors have taken to the streets to bring attention to police brutality, systemic racism, and racial injustice faced by Black and Indigenous people and people of colour in the United States, Canada, Great Britain and some European countries. In many of these protests, outraged citizens have torn down, toppled, or defaced monuments of well-known historic figures associated with colonialism, slavery, racism, and imperialism. Protestors have been demanding the removal of statues and monuments that symbolize slavery, colonial power, and systemic and historical racism. What makes these monuments problematic and what drives these deliberate and spectacular acts of defiance against these omnipresent monuments? Featuring an interview with art historian Charmaine A. Nelson, this article explores the meanings of these forceful, decolonial articulations at this moment. The interview addresses some complex questions related to monumentalization and the public sphere, symbolism and racial in/justice. In so doing, it suggests that monuments of the future need to be reimagined and redefined contemporaneously with shifting social knowledge and generational change.
\end{abstract}

Keywords: decoloniality; gendered representations; monumental recontextualization; public space; racial in/ justice; symbolism; toppled monuments
Christiana Abraham is an Assistant Professor in Communication Studies at Concordia University. She holds a $\mathrm{PhD}$ in Communication Studies from McGill University. Her teaching and research specialities are in critical race studies, visual representations and culture; de/postcoloniality and gender; race, ethnicity and media and transnational and global-South media practices. Her academic interventions are located at the intersections of media, critical race pedagogies, gender, and post/de-colonialization. A scholar, media practitioner, and independent curator, her scholarship is interested in the destabilization and re-visualization of visualities in anti-racist and de-colonial pedagogies. She is the curator of Protests and Pedagogy: Representations, Memories, and Meanings, an archival exhibition that commemorated the fiftieth anniversary of the Sir George Williams Student protest. 


\section{Introduction}

The police killing of George Floyd, an unarmed AfricanAmerican man in Minneapolis, United States, in early 2020 unleashed a wave of angry street protests led by the Black Lives Matter (BLM) movement. Huge anti-racism protests featuring tens of thousands of persons of diverse races and ages, that began largely in the United States, have brought attention to the proliferation of police brutality, systemic racism, and racial in/justice (Cheung 2020; Altman 2020).

The replay in the media of video that captured the arrest and slow, public killing of Floyd sent ripples across the world in the weeks and months that followed, spurring protests in Canada, Europe, and further afield (Bennett et al. 2020; Aljazeera 2020).

As part of these manifestations, protestors have taken to demonstrating against statues and public monuments (MacDonald 2020; Selvin and Solomon 2020). These targeted monuments are viewed as heroizing persons associated with colonialism, slavery, and imperialism. Hence, protestors demand the removal of these symbols of slavery or colonial power. Monuments that have received the most vehement protestations are those representing historical figures, recognized slave traders or owners, or those viewed as having supported outright racist policies against Indigenous, Black, and other racialized people. In these protests, prominent public monuments have been pulled down, defaced, painted over, toppled, graffitied, reconfigured, restaged, and reimagined in myriad ways (Draper 2020; Togoh 2020).

Colonial figures, confederate generals, and slave traders across the United States, Great Britain, and Europe have received the brunt of protestations. In the United States, protestors targeted monuments of Christopher Columbus to whom historical texts have falsely attributed the 'discovery' of the Americas (Dunbar-Ortiz and GilioWhitaker 2016). Also singled out was the statue of American president Andrew Jackson, a slave owner, and General Robert E. Lee, a confederate general who fought on the side of the Confederacy during the American Civil War (Draper 2020). In Bristol, United Kingdom, the statue of Edward Colston was spectacularly toppled by a large crowd and ceremoniously dumped into the harbour (Togoh 2020). Colston was a well-known slave trader who trafficked enslaved people at that very port. In Belgium, statues of King Leopold II were targeted (Rannard 2020). Leopold is known for his violent policies in the Congo Free State in the nineteenth and early twentieth centuries that saw millions of Congolese people killed and maimed (Hochschild 1998).

In Canada, various statues of the first prime minister, Sir John A. Macdonald, were selected. A group protesting against police violence in Montreal, pulled a statue of Macdonald off its plinth such that it was decapitated as it crashed to the ground (CBC 2020). (See Figures 1 and 2).

Activists, demanding that these statues be brought down, say their aim is to change historical narratives and to remind people of the full and complex biographies of these heroized figures who actively participated in the oftengenocidal marginalization of Black and Indigenous people and other people of colour. As David MacDonald writes, "These protests highlight the racism of these infamous figures, the racist societies that produced these representations and the ways these representations and these statues continue to both normalize and obscure settler violence and systemic racism" (MacDonald, 2020).

Noticeable in these overt public performances of dissent are expressions of disdain for representations of colonial and racist power and its racist outcomes. MacDonald describes this aspect of the protests: "Protestors beheaded Christopher Columbus, pitched Edward Colston into the sea, pelted Cecil Rhodes with excrement, doused John A. Macdonald with paint" (2020). Similarly, in London, a statue of Winston Churchill was defaced (see Figure 3); in Antwerp, a statue of King Leopold II was set on fire (Togoh, 2020); and in Cape Town, South Africa, a statue of British imperialist Cecil Rhodes was decapitated (BBC 2020).

These emphatic and symbolic displays re-enact a type of historical poetic street justice that draws attention to the violent nature of colonialism and its lingering legacy. Supporters of this movement say that the offending monuments should be removed, while those who disagree say the past cannot be erased, arguing that those who profited from slavery cannot be judged by today's standards. 


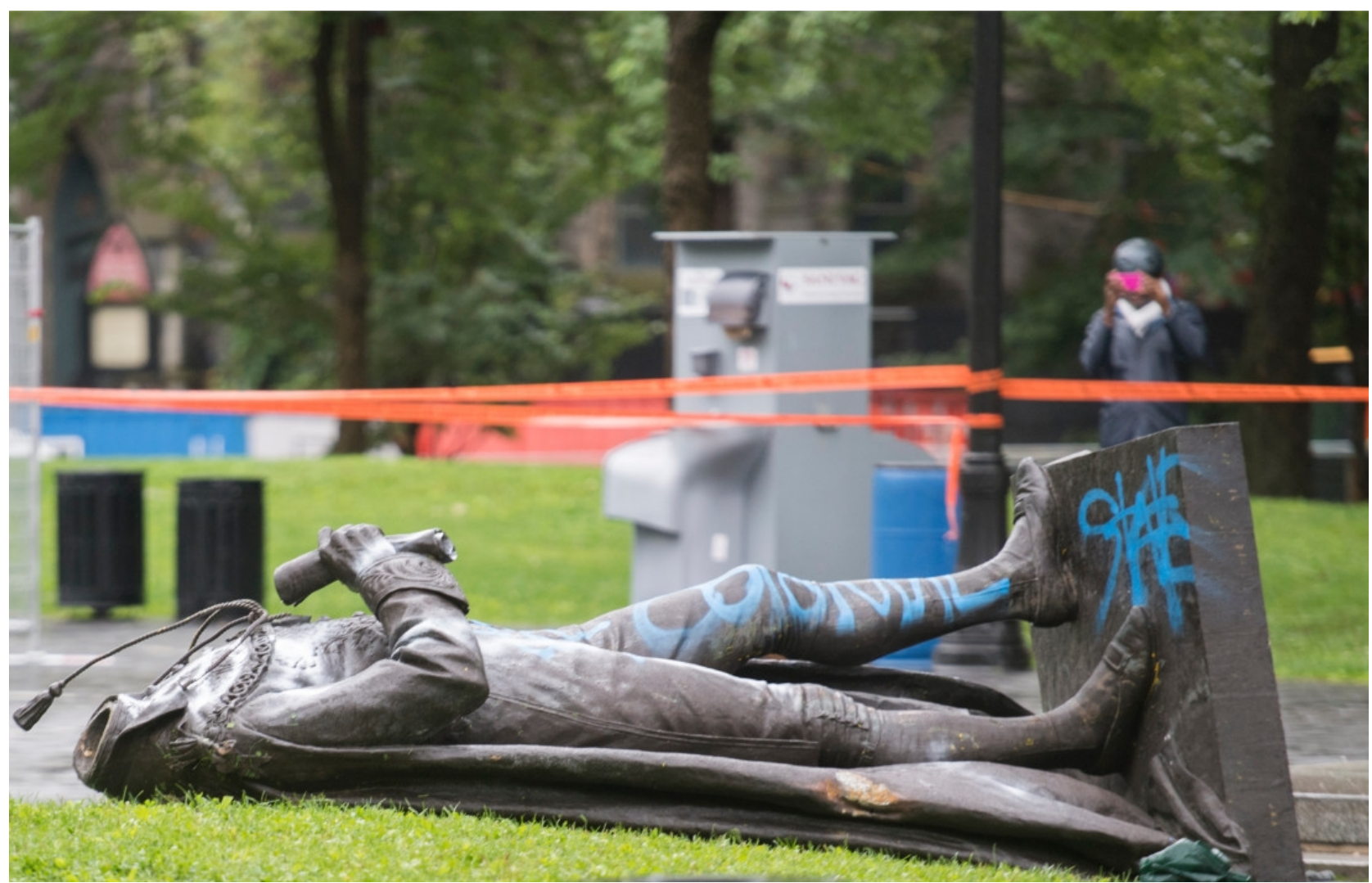

Figure 1: Toppled statue of John A. Macdonald lies on the ground after protestors pull it off its plinth in Montreal. (Photo $($ C Canadian Press MacDonald)

\section{Monuments and Monumentalization}

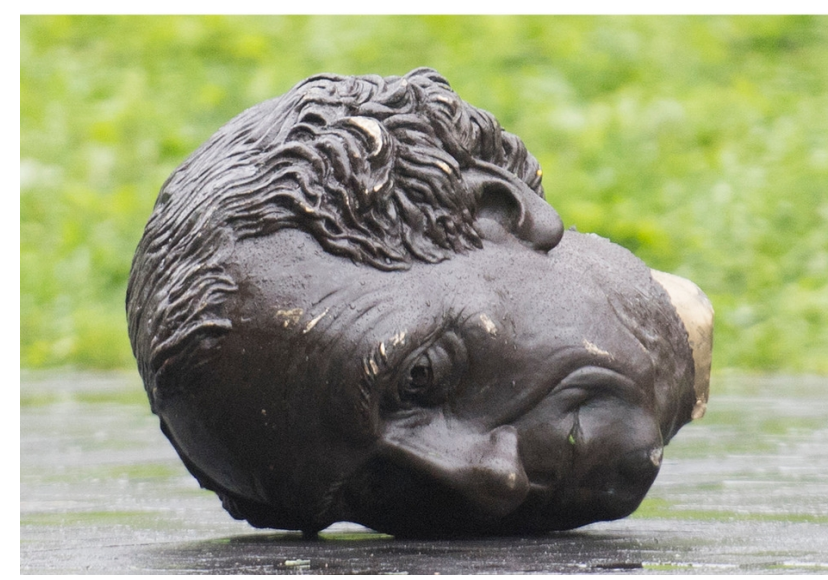

Figure 2: The head of the statue of John A. Macdonad lies a few feet away from the body after the statue was toppled to the ground in Montreal. (Photo (C) Canadian Press MacDonald)
These targeted public sculptures are monumental structures that represent persons who once lived. Cast in stone, marble, iron, or bronze, these larger-than-life figures are usually mounted on tall stone or concrete plinths high above street level. Figures depicted are commonly staged in bold ceremonial wear, sometimes posed on a horse as a representation of human greatness (Dickerman 2018). As spectacles designed to dominate the public space, these monuments and statues are rife with symbolism that conflate lofty imagery with common national identity in the production of myth. They function as collective narratives in the production of heroes worthy of public adoration (Dickerman 2018).

Critical theorists suggest that these monuments are not neutral but powerful technologies that vehiculate selective historical narratives rife with ideology (Nelson 2017). They can be viewed as forceful forms of selected memory framing socially constructed public consciousness which tell the public how they should view historical figures. As Dickerman suggests, "You can think of monuments as 
the expression of forms of collective memory as doing a kind of political editing of the past, what has been excised is made visible in a bid for remembrance" (Dickerman, 190).

These public monuments offer a selection of people deemed the heroes of history by ruling settler governments and powerful lobbying bodies, but these selections reflect hegemonic histories bereft of or blatantly celebrating the imperial violence inherent to them. They offer poignant narratives of those who should be imagined as heroes, but what is problematic is the narratives that are left out of these public displays. The production of monumental heroes simultaneously produces anti-heroes as those characters in history deemed to be forgotten (and forgettable) or symbolically devalued. And these are the unspoken or unwritten histories which are brought into focus by the monumental protests, in both literal and symbolic forms.

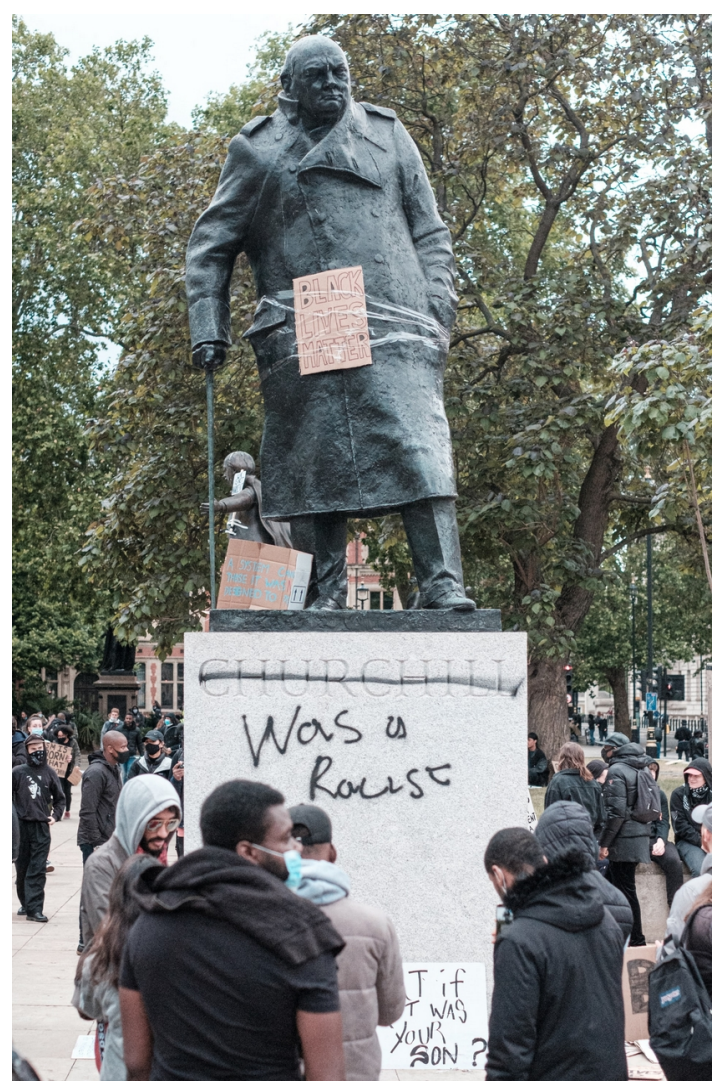

Figure 3. A Statue of Winston Churchill defaced by BLM protestors in London, England, June 2020. (Photo credit: Ehimetalor Akhere Unuabona on Unsplash.)
Statues and monuments are thus built to remind people how to remember history, but their deliberately falling in the act of protest signals a shift in social consciousness about who should be commemorated and how history should be told. The toppling of these monuments can be seen as a symbolic falling of the history that they represent.

\section{Monumental Targeting, Not So New}

Shepherd Mpofu remind us that these acts of deliberate earmarking of monuments are not new. They evoke similar disruptive actions that deliberately targeted colonial monuments by "fallist" movements of the past. Advocates for the falling of statues and monuments, referred to as "fallists" (Mpofu 2017), are ideologically positioned in provoking the symbolic falling of old, oppressive systems that privilege rich and White members of communities while marginalizing minorities and people of colour.

Recent movements such as \#RhodesMustFall led by students in South Africa in 2015, and the United Kingdom, in the following year, deliberately targeted colonial monuments. This student-led movement in South Africa demanded and removal of the statue of Cecil Rhodes at the University of Cape Town (UCT). Rhodes, a notorious colonial-era explorer, is celebrated for his role in the expansion of the British Empire in Africa in the late nineteenth century. But, as John Newsinger points out, to many South Africans, the Rhodes statue is viewed as symbolizing the brutal conquest and exploitation of the African continent through vicious military and clandestine advances that included the capture, rape, torture, and killing of thousands of native Africans in order to lay siege to the land (Newsinger 2016).

Similarly, the \#RhodesMustFall campaign picked up steam at Oxford University by 2016, with a student-led campaign for the removal of the statue of Cecil Rhodes at Oriel College. At Oxford, Rhodes is revered as an important benefactor after whom buildings (Rhodes House) and scholarships (the Rhodes Scholars program) have been named. Student activists on the other hand, view his legacy as an extension of the brutality of British imperialism that should be revisited and made right in the production of historical memory.

To Verity Platt, modern-day "fallist" practices echo philosopher Bruno Latour's notion of "iconoclash" as a powerful form of social change. Iconoclash features the 
clashing of old and new images that results in the public replacement of figurative and literal images with new ones. The falling of monuments, like that of Edward Colston in Bristol, evokes the Roman practice of damnatio memoriae (condemnation of the memory) (Platt 2020), as the ritual removal and destruction of public figures that have fallen from grace.

This equivalence between statue and body is also a striking feature of recent events, as when the fellers of Colston kneeled on his neck in an echo of the death of George Floyd. In an act of symbolic revenge, a figure who profited from the oppression of Black bodies (and whose monument was itself a perpetuation of this oppression) was subjected to the same violence perpetrated by his 21 st-century successors (Platt 2020).

In this case, the physical monuments viewed as stand-ins for colonialism's legacy of systemic violence are forced to undergo similar violence as public ritual which, in the process, produces powerful new images and memories. These acts of tumbling monuments in the current context raise an array of issues about race and racialization, colonialism's knowledges and legacies, police violence, and inequalities. They also raise questions about the monuments themselves. What is their usefulness in changing times, and how can future monumentalization be imagined?

This article explores some of these complex issues associated with the toppling of monuments. It features an interview with Charmaine A. Nelson, Tier I Canada Research Chair in Transatlantic Black Diasporic Art \& Community Engagement at the Nova Scotia College of Art \& Design University (NSCAD), Halifax. Nelson offers an interpretation of the moment through an indepth qualitative interview by discussing the complex nature of race, representation, symbolisms, historicity, and futurism, associated with the recent global toppling of monuments and statues. A former professor in Art History at McGill University, Nelson's research focuses on the Black female figure in western art, postcolonial and Black feminist scholarship, transatlantic slavery and Black diaspora studies. She has made groundbreaking contributions to the fields of the visual culture of slavery, race, and representation, and Black Canadian Studies. A prolific writer and commentator, she has frequently commented on the histories and representation of Black populations in the Canadian media. This interview was conducted in the summer of 2020, via zoom during the COVID-19 shut down, and in the midst of worldwide protests when many monuments came toppling down.

\section{Interview with Charmaine A. Nelson}

\section{Christiana Abrabam (CA): Can you please intro- duce yourself, who you are, and what your work is about?}

Charmaine. A. Nelson (CAN): I am the Canada Research Chair in Black Diasporic Art and Community Engagement at the Nova Scotia College of Art and Design University (NSCAD) which is in Halifax, Nova Scotia. My specialization began by looking at art that represented Black female subjects. So, my MA thesis for instance, focused on mid-twentieth-century Canadian painters who were of European ancestry who focused on Black Canadian female subjects, nudes as well as portraits and figure paintings. Then my $\mathrm{PhD}$ focused on a similar subject, so I stayed with Black female subjects, but I looked at the American context in a slightly earlier period, in the period of just before and during the American Civil War, that was between the 1850 s to about 1875. I looked at many of the artists who sculpted almost exclusively in white marble, so they were known aesthetically as neo-classicists because they looked back to Greek and Roman antiquity as a paradigm or the epitome of art that transpired before them. But what was interesting about them was that many of them were explicitly political in their agendas and in their ideologies in terms of why they made art and what they focused on. What I mean was that a lot of them were abolitionists. Slavery in the United States didn't end until the Civil War in 1865. So, many of these artists deliberately sculpted Black subjects, male and female, ${ }^{1}$ to push for abolition or the end of slavery in their nation. After that period, they pushed for the reconstruction or the creation of a better nation that was not just free of slavery, but that had been reconstructed in terms of racial equity and racial justice.

\section{CA: What is a public monument? Why are monu- ments important?}

CAN: This is something a lot of people generally don't think about unless, let's say, you come from an art history background and you studied public sculpture and monuments before. ${ }^{2}$ It takes a tremendous amount of cultural, social, political, and economic capital to be able 
to erect a public monument. So, if you or I or anybody else wanted to say, "Hey let's just go put a monument up on the corner of St. Catherine's and McGill College boulevard [in Montreal]," we could not do that. You have to work for instance with a municipality or city where you want to erect the monument. You have to be given permission to use that public land. And then, you also require the money and the wherewithal to hire suitable artists, in this case, a sculptor in monumental work.

We need to think of the types of images, or which human beings are memorialized in monuments. This brings us to the question of how it is that our cultural landscapes in Canada and other countries in the West look the way they do? So, many monuments were built to white men, and this raises the question who had the power and the cultural capital? It was white men, historically, from colonial societies built on racial and patriarchal hierarchies that excluded women from having social, political, and legal voices. So, there's a reason why the cultural landscape is so biased towards white males and we need to think about the function of most of these monuments.

Why do we put up monuments? Usually to people we want to heroize or to situations that we're mourning or commemorating, or a monument to a prime minister, a president, a war hero. Often, how you represent that will be through allegory and different symbolism. ${ }^{3}$ But in terms of people who get enshrined in monuments, usually they're people who are deemed to be social heroes for a certain reason. So, here lies the question of the public outcry in this moment and the controversy in who we have chosen to commemorate and heroize in and from the past. These things are being brought into question now.

CA: The issue of public monuments is very important. States and institutions have used them in various forms of public education, to influence bistory and public discourses. How would you describe the role of public historical monuments in Canada?

CAN: We need to understand the role that art and visual cultures played in politics throughout the world, across different spectrums of politics and across different nations. What is the political intention behind representing people in those institutions in that way? In Canada you would find very few eighteenth-century monuments, in part, because we just didn't have the art schools, artists, and professional sculptors established in that period. We remained loyal to the British Empire during the Revolutionary War and so when Britain abolished slavery in 1834 we were a part of the British Empire. We didn't have an explosion of monuments in the years after that, like the USA because a lot of the Confederate monuments [in the United States] didn't go up right after the Civil War was over. They went up a few years later.

So, we don't have the same history in Canada of fighting a war to end slavery. That is what the civil war was. ${ }^{4}$ In the USA, the North wanted to end slavery and the South wanted just keep slavery and expand it. There was a nostalgia for slavery that sparked that cultural proliferation and the growth in those monuments in the South.

So, as a nation we don't have as many public monuments as the US, but that's not to say that we don't have colonial and racist monuments. We do. We do have the Nelson monuments, the Queen Victorias, ${ }^{5}$ the Sir John A. MacDonalds, ${ }^{6}$ but they look different because our national history is different. Montreal is interesting because you have a set of monuments that have been put up to mainly white male colonizers, either British or French. ${ }^{7}$ There are dual monuments in the city because of the history of French colonization, then British conquest that you wouldn't see in other provinces in the same way. In Canada, many of our monuments show a nostalgia for colonial conquest.

\section{CA: In what specific ways are these colonial monuments problematic?}

CAN: I say to Black and Indigenous people and people of colour, what do these monuments do? If you go to the De Maisonneuve monument in old Montreal, across from the Notre-Dame Basilica, you would see a kneeling Indigenous figure at the feet of De Maisonneuve, who is a White francophone hero raised on a pedestal. ${ }^{8}$ The kneeling Indigenous figure is not meant to be a portrait. It is not a specific Indigenous man. It is just supposed to be a crouching, abject Indigenous figure. [See Figures 4 and 5]

This is what is done to Black and Indigenous figures all of the time throughout the history of western sculpture. For example, consider the crouching Black man, kneeling beneath Lincoln's extended hand in all the abolitionist monuments [in the US]. We need to think about how Black and Indigenous people and people of colour are 


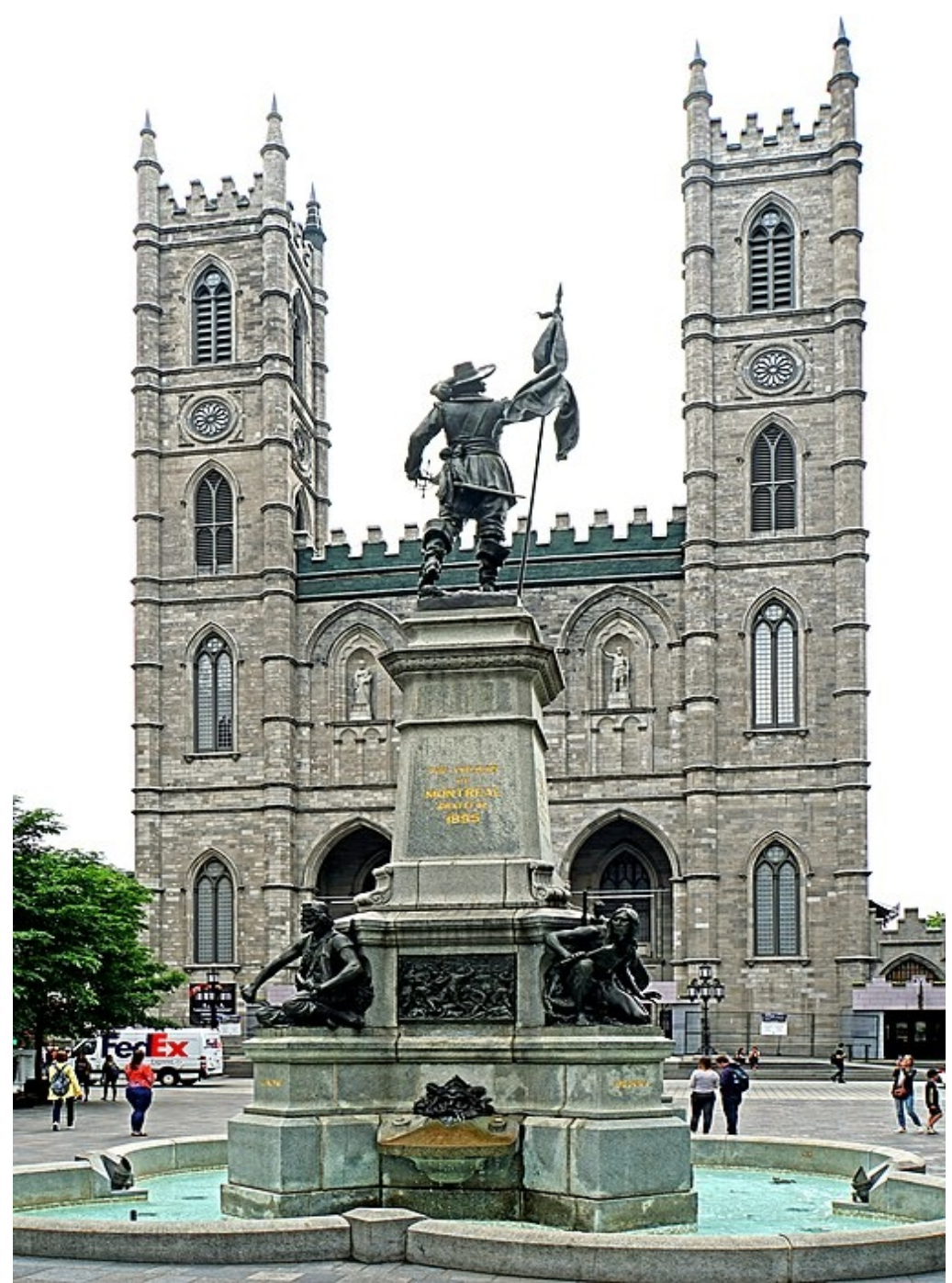

Figure 4. A grand statue of Paul Chomedy de Maisonneuve, founder of Montreal, outside the Notre-Dame Basilica in Montreal, featuring an Indigenous figure at the statue's base. (Photo credit: Maisonneuve Monument and Basilica by Dennis Jarvis, licensed with CC BY-SA 2.0.)

incorporated in these monuments. If they are there at all, they're almost never the central figure. This is what we need to think about. [See Figure 6.]

To whom are those monuments built and how then do we have to redress this idea of what history is. Let's be frank, history is written by the victors. So, Black people and Indigenous people never made anything worthy of contemplation? Of course that's false! This idea that the monument is a factual representation of a history that's written in stone that is handed down from a deity? That's wrong. So that's something that needs to be disrupted, especially in the Canadian context, because we don't have the background in Canadian history or in art history as a lay public or in academia. So, we need to think about what is the background that Canadians need to be able to approach these monuments critically and with some knowledge, in terms of the complexity of those histories and frankly, the falseness of the histories that have been written until this point.

CA: What are some of the ways in which we can approach this practice of monument building in the Canadian public space in terms of gender? It is clear that there is a scarcity of women's monuments and statues in the public spaces in which we live, however women have always been there, and they have done significant things.

CAN: The absence of depictions of women in monuments in the Canadian cultural landscape is directly con- 
nected to sexism and racism in our society. Of course, this deficit has impacted all women, but Black and Indigenous women and women of colour most profoundly. Traditionally, the women who have been represented have been white women of the upper classes-like Queen Victoria-or female allegories who are often coupled with portraits of white men. These allegories are not portraits-representations of individual females who lived-but symbolic representations of things like victory, death etc., that provide a context for the deeds of the man/men who are customarily the central figures. Although women have always made significant contributions to Canadian society, we have not been represented as individual human beings in monuments because we have been denied the cultural, economic, and political capital that it takes to erect monuments in public spaces. But if we claim to be an inclusive society that acknowledges and seeks to dismantle systemic racism and sexism, we must commit to the radical diversification of the Canadian cultural landscape which includes its monuments. ${ }^{9}$

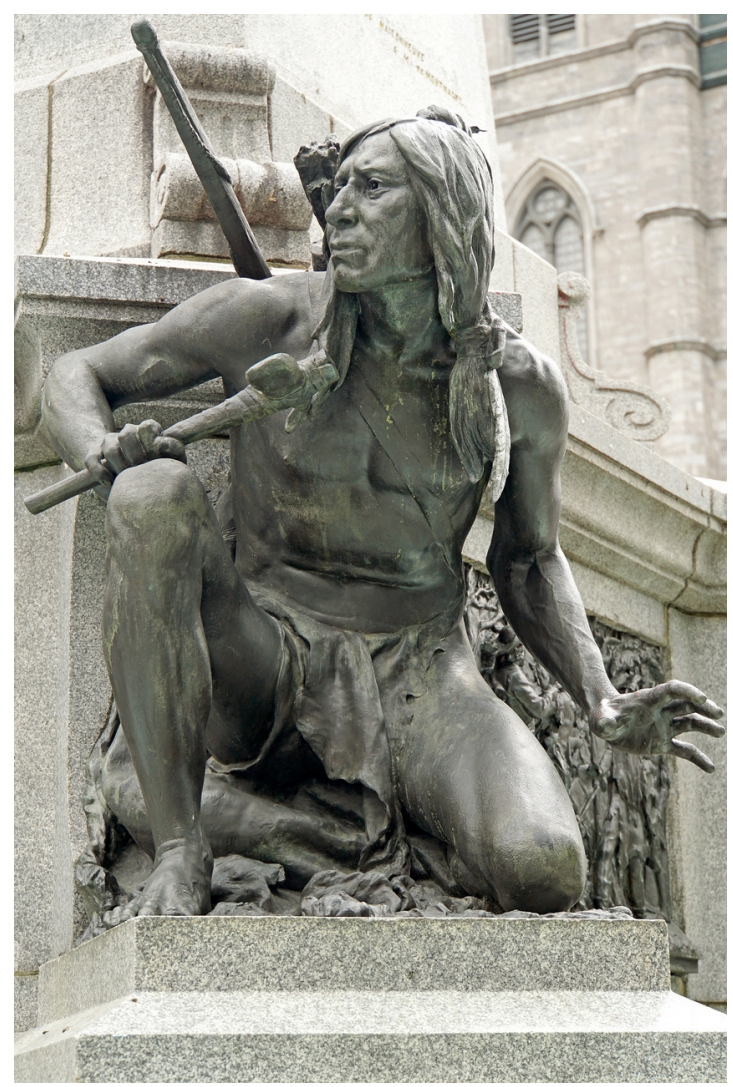

Figure 5. Iroquois figure at the base of the statue of Paul Chomedy de Maisonneuve at Notre Dame Basilica in Montreal. (Photo credit: "Iroquois" by archer10 (Dennis) licensed with CC BY-SA 2.0.)
CA: What is the significance of the recent public backlash against monuments in particular in the United States and Great Britain in response the Black Lives Matter (BLM) movement?

CAN: I think the example of the Edward Colston monument is an interesting one. The monument to Edward Colston in Bristol [England] dates from 1895, that is way after he had died. The monument went up at least six decades after Britain abolished slavery. Britain abolished slavery in 1834 . They put up a monument in Bristol which was one of the central slave ports, a place where ships left for Africa with manufactured goods and then in Africa these wares were sold and enslaved human beings loaded on the same slave ships as cargo. Colston was a slave trader, and it is well known through archived documents that he enslaved at least one hundred thousand people. ${ }^{10}$ What business did the people in Britain have putting up a monument of this man which implies that they literally heroized him sixty-years after the abolition of slavery? This is where you get the expression "putting someone on a pedestal." To put someone on a pedestal means to raise them above the general public in terms of the good things for which they deserve to be honoured.

So, Black Lives Matter protestors ripped down the monument and rolled it in the harbour. It was symbolically beautiful because part of that was a refusal to look at this man as a hero. The protestors were saying, "The governments of this municipality, region, or nation have to start to listen to us, a diverse public about who we deem fit to be heroized and commemorated in the public space. Someone who stands accused of helping to enslave one hundred thousand people of African descent is not someone who we choose to heroize at this moment when we still have Black people, and people of colour dying from police brutality."

CA: In many Canadian cities, monuments to Sir John A. Macdonald, Canada's first prime minister, have been regularly targeted by protestors or small groups. What is it about this monument in particular that draws such protestations?

CAN: In a place like Montreal, the monument to Sir John A. Macdonald was put up in 1895 , several years after he had concluded his second term in office, and it's been the site of a lot of attacks over the years. People have chopped the head off, painted it red, or graffitied 
the monument. The city just goes back and cleans it up. I saw the Mayor of Montreal on TV who said, "Why don't we just put a plaque on the side of the monument to contextualize who he was."

So, let's break this down for those who do not understand why people are so vehement in their protests against that monument. Sir John A. Macdonald was the first prime minister of Canada and central in the Confederation as we know it, or the pulling together of certain provinces into a nation. This is very important. He is also applauded for building the Canadian Pacific Railroad across Canada. But for that, he used large numbers of exploited immigrant Chinese male labour. We know, through documents and archival research that often these Chinese men's lives were valued less than those of white lives. They were given the most dangerous of jobs in terms of working with explosives, for instance. That same government tried to ensure that they would not be able to stay on permanently and become Canadian citizens and migrate their families to Canada to join them.

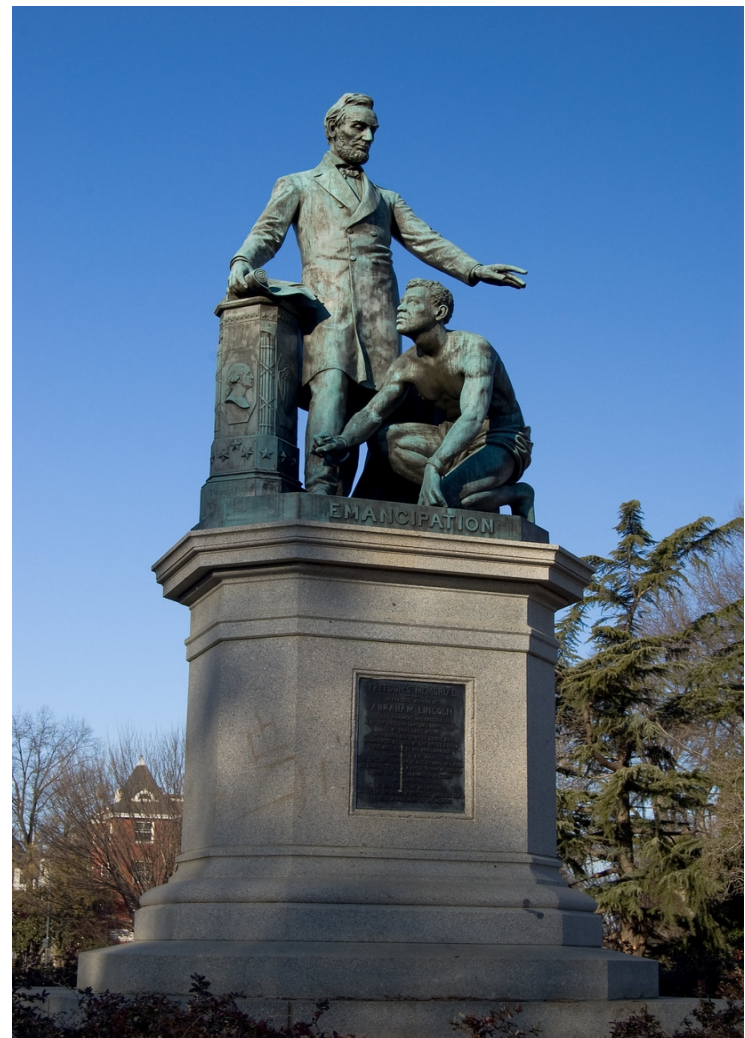

Figure 6. A freed slave kneeling at the foot of US President Abraham Lincoln in a monument to celebrate the emancipation of slavery.
Macdonald is also responsible for helping to develop the residential school system that is responsible for genocidal practices against Indigenous people, especially Indigenous children, who were literally kidnapped from their families. The system was aimed at trying to transform them into 'White' children by literally breaking them of their ability to communicate linguistically and culturally with their Elders. We know from the Truth and Reconciliation Commission, and long before that, the horrific outcomes in terms of suicides, deaths, and prolific racialized pedophilia that occurred in those spaces. ${ }^{11}$ So, John A. Macdonald's statues are being attacked for a reason.

To go back to the Mayor, this idea of sticking a plaque on it and then people will know how complex this history is to me "No"! We have to understand how taking up of public space by the monument and the fact that it is larger than life size, sitting on a pedestal, usually is telling the person standing in front of it that you are to commemorate this person as a hero.

\section{CA: Can you comment more directly on the recent toppling of the Sir John A. Macdonald in Montreal (September 2020) within the context of BLM and defunding of the police protests? How can this act of monument disruption be read?}

CAN: Before the monument was toppled [see Figures 1 and 2], I warned in a CBC interview that it was coming. I thought this would be the case because it has been the target of political protests for years. But as calls grew for politicians to revisit the explicitly racist nature of our cultural landscapes and public monuments in the USA, like Confederate monuments in the South, in Canadalike Edward Cornwallis in Halifax ${ }^{12}$-and in the UK, like the slave trader Edward Colston, the Macdonald statute became a more fervent target of protests. For many Canadians who do not understand or support the BLM movement, or other protests movements which routinely target colonial public monuments, they revere Macdonald as a symbol of Canadian unity and have a difficult time exploring his full and complex biography which includes genocidal injustices and grave harms against Indigenous, Chinese, and other people of colour (Cho 2013). It is quite similar to the reverence that many Americans heap upon their White founding fathers in spite of the fact that several enslaved people of African descent. If asked today, would most Americans agree with a decision to remove George Washington from the $\$ 1$ bill? I don't think so. This is the kind of fer- 
vour that some Canadians feel for Macdonald. However, if the City of Montreal does not move to replace the Macdonald monument and instead places it in a museum, for instance, we will have an opportunity for a fuller and more complicated conversation about who he was and the deeds that he committed and authorized in his lifetime.

So, when people were losing their minds over the potential of John A. Macdonald coming down because of how the history will be "damaged" and the resulting "false" history that will be provoked, the thing that they needed to understand is that in 1895 , when that monument to Macdonald went up, do you think Indigenous, Black people, and Chinese Canadians in Montreal liked that monument? I bet you the answer was no, but no one asked them. Our ancestors were never consulted about these things because we didn't have the power, because the state was busy making sure we were disenfranchised. Think about the way classism and racism intersect to this day. You block people from accessing certain schools, you disallow them from attaining certain knowledge, you redline neighbourhoods so they can't get a mortgage to buy a certain house in a neighbourhood with proper facilities and amenities, all of this is going on historically and still today.

\section{CA: What is the importance of this type of bold, public decolonial activism in Canada?}

CAN: Very important! In general, most Canadians have no idea about the nation's colonial history. They don't understand how Canada became Canada; they don't understand about Indigenous dispossession. They certainly don't understand that we had at least two hundred years of transatlantic slavery where both Black and Indigenous people were enslaved in a province like Quebec, and Black people were enslaved from Ontario all the way to Newfoundland.

Therefore, our conversations about monuments as colonial are not based upon a full understanding of these contexts because we don't know how to grapple with the complexity of colonial history. Some people can't hold these two thoughts in their minds at the same time-Sir John Macdonald central in founding the nation of Canada and Sir John Macdonald central in the architecture of the residential school system and the death and harm of many Chinese male immigrants. They can't hold these two thoughts at the same time. ${ }^{13}$

\section{CA: How do you believe the work of these monu- ments and statues deemed offensive can be deac- tivated, so to speak?}

CAN: So, how we deactivate that monument is by taking it down. In Halifax in 2018, for example, the municipality removed a statue of Cornwallis who was a first governor, who was vehemently racist against Indigenous and Black people. There was a vote at the level of city council where a majority voted to have that monument taken down. As an art historian, I don't want to see these monuments destroyed because I am not for censorship. But I think they need to be critically re-contextualized within an anti-racist, or post-colonial art historical practice. And how can we do that? Perhaps to put them in a museum, if the museum has the tools, meaning the curators who have the ability to re-narrate the monuments in all of their complexity. Now, this is a big "if" in Canada because museums and galleries are guilty of institutional racism and the underemployment of staff who are Black, Indigenous and people of colour. So which museums are we going to give these monuments to at the moment? That's another conversation but a conversation that is needed as well.

\section{CA: In what other ways do you believe publics can reject, dissent, or speak back to these import- ant, imposing forms of public art?}

CAN: Part of what we have to think about is [if we] are a society that believes that monuments still have work to do? If so, then what is the work of the monument? How long is any given monument of value to us, or valid, in terms of intersecting with a public? This gets complex because something we might want to put up today, in 2020, our descendants might say, "What were they thinking? Who is this person? I don't get it". Do we just accept then that if every generation puts their monuments up, the next generations might take them down so that monuments aren't forever.

This is hard for people to deal with because of the very materiality of the monument, the fact that they are usually built in stone, marble, metal, or bronze, which are supposed to symbolize in their very materiality that they are permanent. So, what happens if we start to say, "They are generational."

Here's a case in point. The monument to British Admiral Nelson, in Old Montreal, may be the oldest monument 
in Montreal, built in 1809. This was about five decades after British conquest over the French. The French did not like that monument, and that monument was a site of a lot of francophone graffiti for years. They were like, "Let's paint on it. Let's draw on it. Let's hack it up. Let's try to knock it down", because there wasn't consensus about the monument. French Canadians in Quebec took strong offence to this statue because of Admiral Nelson's role in defeating the French. Rich Scottish and English men who wanted to heroize and commemorate Nelson put up the monument. So, these issues aren't new, but we have to be expansive and truthful about how we think and talk about them and about what possibilities lie in the future in contesting these monuments. Do you rip them down all together?

This also makes me think of other more recent techniques of dissent, like yarn bombing. Yarn bombing was done by female artists [in the US and UK] who were knitters who would put up a knitted cloak over the monuments that they thought were racist and sexist. ${ }^{14}$ The use of knitting was instrumental because knitting is usually dismissed as a female domestic form of craft (meaning not 'high' art), that women do at home. Instead of pulling down the offensive monument like Black Lives Matter protestors did with the Colston statue, which is another way to go about it, they would instead put these very colourful, almost fantastical, knitting over the top of the entire monument. So, the act of covering the things that they were critiquing in the public sphere was a very powerful way to bring a spotlight to why they thought these monuments, relics, or artefacts in public places needed to go.

CA: At this juncture, these public actions have forced pertinent discussions on the colonial role of these monuments and the necessity of decolonial responses to them. How do you believe future projects of monumentalization should be conceptualized?

CAN: We have to think of the types of interventions and new forms of commemoration that make permanent or non-permanent interventions. For example, under the presidency of Barack Obama, celebrated enslaved runaway freedom fighter and conductor on the Underground Railroad, Harriet Tubman had been chosen to replace Andrew Jackson on the $\$ 20$ bill.

In Canada, we have a new $\$ 10$ bill with Viola Desmond on it, a Black woman, who is a twentieth-century civil rights hero from Halifax, Nova Scotia. ${ }^{15}$ The symbolism of those women being on the currency is very powerful because the currency is also a space for portraiture and people that are revered in any nation, and usually that's White men in Western nations, certainly not women or women of colour.

But people have found it potentially offensive to have someone like Harriet Tubman who was enslaved herself, who was treated as a form of chattel, who was exchanged for currency, to end up on currency. So, we have to think critically about the interventions we make, if they are appropriate and that's a debate we need to have. Is that the most appropriate way for us to salute her, to heroize her, to remember her and her wonderful legacy?

The thing I want to point out, if I may, is the complexity of the question you are bringing to bear. We have to be sure we don't conflate two things and that is, where are the relics to the transatlantic slavery for instance that are still left in the landscape, and how can they be mobilized as a kind of natural form of sculpture that brings us to a confrontation with histories that are often uncomfortable? Also, where should we be building new monuments?

Allow me to share two recent examples. There was a newspaper article about a slave auction block on the corner of a street in the small town of Fredericksburg in Virginia. Some people in the town were saying, "Knock the slave block down, it's inappropriate. It's reminding us of slavery." And the Mayor's position was, "Listen, the block isn't a commemoration to slavery, the block IS the history of slavery ${ }^{16}$ and the fact that the block makes you uncomfortable is actually good in this case, because many of you don't want to remember the role our town played in slavery." ${ }^{17}$

So, you see the difference? This is the difference that all of us need to get. The difference between a relic that actually is of the history, that was created of the history, and how that can provoke us to change and to think, as opposed to someone coming in and building a monument to slave owners or slave traders.

The other example I wanted to share is of the National Monument for Peace and Justice that was built in 2018 in Montgomery, Alabama, in the USA. ${ }^{18}$ That's a monument to people who suffered slavery in the USA, who suffered the terror of lynching, who were murdered by 
white mobs. These were mainly African-American men and often some women and some people of other races as well. It is a six-acre memorial with engravings of every name, or "unknown" in some cases, of the individuals who were murdered at the hands of white mobs. It features also the strategic uses of monuments in the space that deal with histories of slavery and the histories of different moments of different racial injustice in the USA, also interspersed with the words of African-American leaders, like Ida B. Wells.

So, that is a completely different undertaking than the monuments that are being attacked now by a lot of the public and by groups like Black Lives Matter. This is an example of a monument done right. ${ }^{19}$ It is not just a one-off object but a space of contemplation that is also recording and commemorating a history of brutality.

\section{CA: It is clear that youth are playing a pivotal role in this transnational monumental decolonial activism. What inspiration are we to take from this generation's activism? And what advice would you offer to those contemplating on his- tory's lessons in this movement?}

CAN: It is great to see how active the youth are in these recent political movements for social justice, however, they must also remember that "the fight" has been going on for generations before them and they still have things to learn from their elders. They are indeed standing on the shoulders of giants, many of whose names they may never know, but whose bravery and defiance in the face of terror made the public activism of 2020 possible. I would also always urge people to think, read, research and to admit what they do not know. Arrogance is an impediment to knowledge-seeking, and we must all be wary of this. Intolerance often goes hand-in-hand with the seeking of justice because people come to only see their path, their way, their story, their claims, their strategies as valid. We are living in an extremely partisan, hate-filled moment, and listening and understanding can take us a long way. The youth must also recognize that the political right is not the only group guilty of intolerance. Indeed, the left has weaponized "cancel culture" in ways that may harm its own movements and goals. Finally, although it is wonderful to see the racial diversity in the protest movement around Black Lives Matter, the idea of "wokeness" should not allow White people to again feel emboldened to interpret, represent, and inhabit Black experience and suffering. That will not result in more justice but a continuation of White privilege masquerading as allyship.

\section{Conclusion}

This interview raises an array of complex issues relating to the revisiting of colonial knowledges and related historical, racial injustices represented by these public enactments of monument toppling in the immediate aftermath of the killing of George Floyd. It raises important questions about the global movement to decolonize public spaces-whose public and what history is remembered with colonial monuments.

It underscores the problematic nature of the thousands of imposing monuments that populate public spaces that symbolically represent the impact of colonialism and its ongoing legacies. Shohat and Stam (2014) draw attention to the functioning of colonialism as a project of global domination of subject Black, Indigenous, and Brown populations encountered in conquest, while Indigenous activists and theorists insist that colonial domination is not only a practice of the past, but an ongoing part of the present (Barker 2009).

These monuments in question bear testimony to colonialism's horrific legacies of conquest, racial violence, and systematic categorization of knowledge in the production of "otherness", through the marking of hierarchized bodies, some of whom were determined heroes, worthy of public remembrance, and others that were deemed disposable life. This revisiting of monuments through grounded decolonization activism lays bare the simplicity and outright falseness of complex historical narratives such as colonial conquest, wars, surrender or treaty negotiation, and catastrophic loss of life that have been reduced to the commemoration of, often, one White male hero. At this juncture, the reductive reproduction of complex national memories that these colonial monuments represent are challenged from the ground up as forceful forms of public actions that attempt to deconstruct and denaturalize myriad accounts of nationalism and nation building.

The performances of these monuments as representations of national heroes in public spaces enact double forms of epistemic violence: firstly, in the airbrushing and re-presentation of violent colonial historical figures as heroes; secondly, in the re-enactment of deep epistemic wounds in the production of individual and col- 
lective identities of those who encounter them. These monuments thus validate the continued domination of the inheritors of colonial power while negating the presence of others through dramatic erasures of large intersectional groups of gendered, classed, and racialized persons in so-called Canadian society. The tearing down of monuments is no simple act, but profound decolonial manifestations that strike at the heart of the epistemic legacies of colonialism's false, biased, racist, and misogynist histories and practices that continue to echo today.

\section{As Verity Platt argues:}

Iconoclasm and damnatio memoriae teach us that monuments are only as powerful as the human will that keeps them in place. With a shift in public attitude towards the living bodies of Black individuals, the imposing bases and columns that had enshrined the hollow bodies of their ancestral

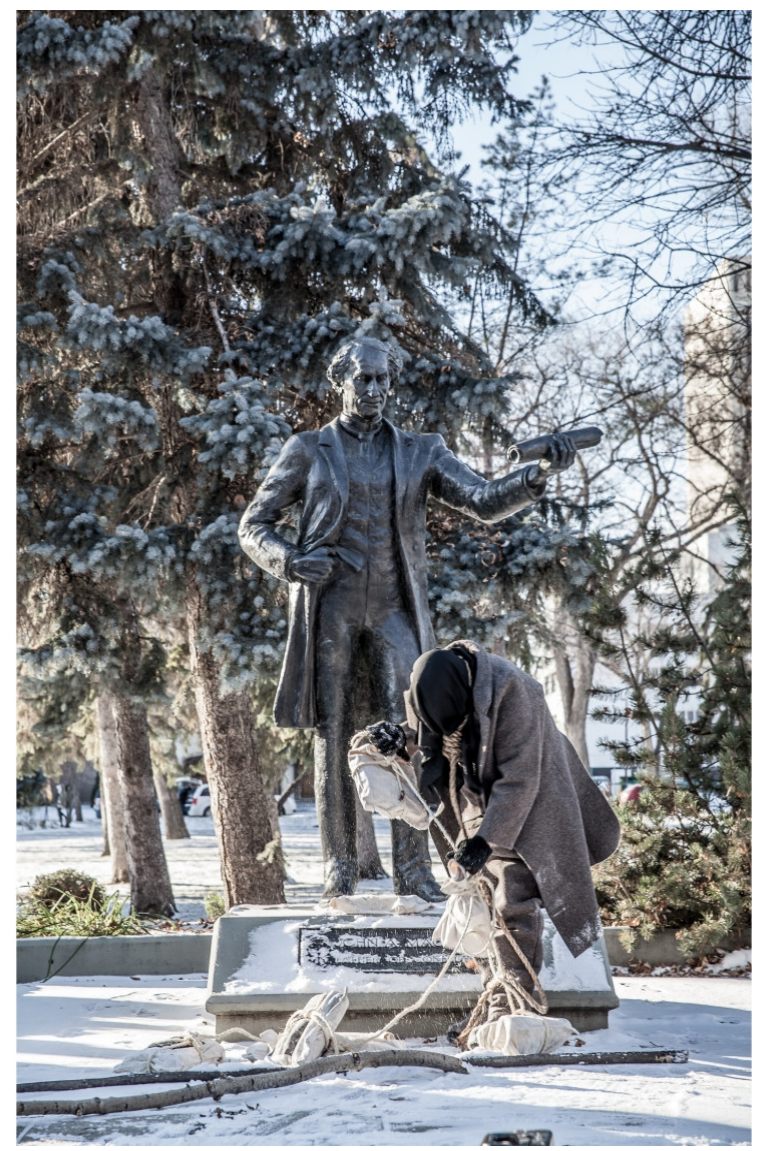

Figure 7. David Garneau's Dear John: Louis Riel performance in Regina, 2014. (Photo OEagleclaw Thom; used with permission) oppressors no longer have the ability to elevate and protect. Now the work begins to dismantle the less visible institutional structures that such monuments were designed to fortify. (Platt 2020)

In as much as this knowledge has been challenged in other domains in the past few decades, the time of reckoning for these reminders of history etched in public squares is at hand.

Decolonising public spaces have to be part of a larger process demanding that these public sites of knowledge become more democratic, not in forgetting the past but in acknowledging their complexity and relationship with the present. As Ronald Rudin suggests, a bold, more temporal approach may be needed in rethinking the future of public monuments where contemporary themes, personalities, and ideas mingle with the past: "For minority groups this means seeing themselves represented in ways that recognize their historical marginalization, but also go well beyond that, making their contemporary perspectives and experiences a part of civic culture" (Rudin 2021).

How do we imagine inclusive representative futures for Black and Indigenous people and gendered, and diverse communities in urban and rural public spaces? Recent Indigenous artists' performative confrontations with colonial statues offer examples of monumental engagement. In a performance at a John A. Macdonald statue in Regina, in 2014, entitled "Dear John: Louis Riel", David Garneau, a Métis artist and scholar, dressed as Louis Riel, holds a silent conversation with the statue. Garneau's performance marked the 129th anniversary of the death of Riel, a Métis leader who was hung in a mass hanging of Métis resistance fighters in Regina in 1885. Macdonald was instrumental in Riel's execution as well as the implementation of aggressive measures such as the Indian Act and Indian Pass Laws aimed at assimilating Métis and First Nations peoples into colonial society. (Garneau 2019). (See Figure 7.)

In this performance, the spirit of Louis Riel confronts the statue of John A. Macdonald using symbolic props and Indigenous artefacts in order for Canadians to see these monuments from an Indigenous point of view, to "nudge them in reconsidering their celebration of Macdonald in Canada." Garneau suggests that when Indigenous artists engage colonial monuments in public spaces, they engage these sculptures not merely as things 
or even representations but as "having being" (Garneau 2019). Following this and other protestations, the Regina City Council voted in the spring of 2021 to remove this statue of Macdonald in Victoria park. It has since been placed in storage (Atter 2021).

The challenge that the Floyd case lays bare for this generation is the continued creative engagement with and rethinking of monumentalization that shifts from commemorating simple and static narratives of the past. In this way, monuments as a part of the everyday experience become sites of justice and social inclusion that commemorate the social condition- $\mathrm{a}$ monumental challenge in process.

\section{Acknowlegements}

The author wishes to thank Charmaine N. Nelson for her time and review suggestions for this interview, Research Assistant Houda Kerkadi, for interview transcription, and David Sauvé for technical support. The author also thanks the editors of Atlantis and the anonymous reviewers for their useful suggestions.

\section{Endnotes}

1. For further reading see: Nelson, 2007. The Color of Stone.

2. Public monuments differ from patronage installations which are funded by powerful patrons associated with particular artists. Public monuments, on the other hand, promote broader national histories, identities, and politics. For more on public monuments' political and aesthetic functions see: Bellentani and Panico, 2016. For more on patronage installation see: Cohns, 1998.

3. Allegory in art refers to uses of elements (in the referenced art) that symbolize deeper meanings, e.g., life, death, or victory. These create extended metaphors that convey art's underlying narratives. For more on allegory see:https://www.tate.org.uk/art/art-terms/a/allegory

4. Maureen Elgersman Lee suggests that Canada's relationship to the end of slavery was a piecemeal affair (Elgersman Lee 1999).

5. Queen Victoria is celebrated as the "mother of Canadian Confederation," the constitutional Monarch who supported the initial development of the Dominion of
Canada (Rayburn and Harris 2015). Monuments to Victoria can be found on Parliament Hill (Ottawa), Stanley Park (Vancouver BC), Manitoba Legislative Building (Winnipeg MB), and Victoria Square (Montreal QC), among others. For more on the thirteen-foot statue of Queen Victoria commissioned by British Colombia pemier Richard McBride in 1912 see: https://www.leg.bc.ca/dyl/Pages/Queen-Victoria.aspx

6. Monuments to John A Macdonald, Canada's first prime minister, can be found in most large cities in Canada, such as Ottawa, Montreal, Toronto, Halifax, Victoria, etc. A number of public buildings such as schools have been named after Macdonald over the years, although there has been concerted efforts to remove some of these. For more on some remaining monuments see Yun, 2018.

7. Popular monuments to francophone "heroes" in Quebec are to French navigators and explorers Samuel de Champlain and Jacques Cartier: https://artpublicmontreal.ca/en/oeuvre/monument-a-jacques-cartier/. Similarly, well-known monuments to English "heroes" include Queen Victoria, James McGill, slave owner philanthropist, and Admiral Horatio Nelson (https://en.wikipedia.org/wiki/Nelson\%27s_Column,_MontrealRobert).

8. For more on the monument to Paul de Chomedey de Maisonneuve, founder of Montreal, see :https://artpublic.ville.montreal.qc.ca/en/oeuvre/monument-a-paul-dechomedey-sieur-de-maisonneuve/

9. The monument on Parliament Hill, Ottawa, to the five famous women who fought for women's voting rights in Canada (Women are Persons!) represents a shift away from monuments to female characters such as Queen Victoria. Viewed as the culmination of popular feminism, this is an example of emerging and contemporary expressions of power. However, the five women have been the subject of controversy, criticized as racist and elitist in their support for eugenics laws that led to forced sterilization of Indigenous women. See James Marsh (2015). This monument also simplifies the complex social attainment of the vote, where Black and minority women's roles in the process are not acknowledged. For a visual reference see: https:// www.canada.ca/en/canadian-heritage/services/art-monuments/monuments/women-are-persons.html

10. Edward Colston (1636- 721) was an English mer- 
chant and member of Parliament who was involved in the Atlantic slave trade. An eighteen-foot bronze statue of his likeness was erected to him in honour of his philanthropic works. For more on Colston see Farrar, 2020.

11. The report of the Truth and Reconciliation Commission released in 2015 recognizes the trauma and suffering experienced by Indigenous children at these residential schools across Canada. See: http://nctr.ca/assets/reports/Final\%20Reports/

Executive_Summary_English_Web.pdf

12. Edward Cornwallis, army officer and colonial administrator, is recognized as the founder of Halifax, Nova Scotia. He is considered a controversial figure who issued two scalping proclamations that offered cash bounties ("Ten guineas for every Indian taken or destroyed") on Mi'kmaq persons. https://

www.aptnnews.ca/national-news/not-forgotten-mikmaqbounty-never-rescinded

13. For more on Macdonald's role relating to the Indian Residential Schools and Chinese migrant /indentured labour see Stanley, 2016.

14. For more on yarn bombing see: https://www.widewalls.ch/magazine/what-is-yarn-bombing

15. Viola Desmond is the first woman to be featured on Canada's ten-dollar bill. Desmond was a Black rights activist who was jailed for defiantly sitting in the "whites only"'section of a Nova Scotia’s cinema in 1946. She represents the often-unacknowledged history of racial segregation in Canada. In 2018, Desmond's image replaced that of Sir John A. Macdonald, Canada's first prime minister on the note. See: https:// www.bankofcanada.ca/banknotes/vertical10/

16. For more on this slave auction block see: https:// www.fredericksburgva.gov/1287/Slave-Auction-Blockslave

17. In an analysis of slavery and the Black body, McKittrick argues for the re-visioning of society, culture, and space from the vantage point of the slave auction block (McKittrick 2006).

18. The National Memorial for Peace and Justice sits on a six-acre site overlooking Montgomery, Alabama. It is informally known as the lynching memorial and com- memorates slaves and other Black persons who were racially terrorized in the United States. Opened in 2018, it advocates for social justice.

19. For a virtual tour of the National Memorial for Peace and Justice see: https://museumandmemorial.eji.org

\section{Works Cited}

Aljazeera News, 2020. "A Timeline of the George Floyd and Anti-Police Brutality protests." June 11, 2020. https://www.aljazeera.com/news/2020/6/11/a-timeline-ofthe-george-floyd-and-anti-police-brutality-protests

Altman, Alex. 2020."Why the Killing of George Floyd Sparked an American Uprising." Time, June 2020. https://time.com/5847967/george-floyd-protests-trump/

Atter, Heidi, 2021. "Sir John A. Macdonald Statue removed from Regina's Victoria Park" CBC News, April 13, 2021. https://www.cbc.ca/news/canada/saskatchewan/john-a-macdonald-statue-1.5986074

Barker, J. Adam, 2009. “The Contemporary Reality of Canadian Imperial Settler Colonialism and the Hybrid Colonial State." The American Quarterly 33, no. 3 (Summer): 325-351.

BBC News, 2020. "Cecil Rhodes statue in Cape Town has head removed." July 15, 2020. https://www.bbc.com/news/world-africa-53420403

Bellentani, Federico, and Mario Panico, 2016. "The Meanings of Monuments and Memorials: Toward a Semiotic Approach.” Punctum 2, no.1: 28-46.

Bennett, Dalton, Joyce Lee and Sarah Cahlan, 2020. "The Death of George Floyd: What video and other records show about his final minutes." The Washington Post, May, 30 2020. https://www.washingtonpost.com/nation/2020/05/30/video-timeline-george-floyd-death/? $\operatorname{arc} 404=$ true

CBC News, 2020. "Activists Topple the Statue of John A Macdonald in Downtown Montreal." August 29, 2020. https://www.cbc.ca/news/canada/montreal/defund-police-protest-black-lives-matter-1.5705101

Cheung, Helier, 2020. "George Floyd Death: Why US protests are so powerful this time." BBC News, June 8, 2020. https://www.bbc.com/news/world-us-canada52969905 
Cho, Lily, 2013. "Redress Revisited: Citizenship and the Chinese Canadian Head Tax." In Reconciling Canada Historical Injustices and the Contemporary Culture of Redress, Eds. Jennifer Henderson \& Pauline Wakeham. Toronto: University of Toronto Press

Dickerman, Leah, 2018. "Monumental Propaganda." October 165 (August): 178-191.

Draper, Robert, 2020. “Toppling Statues is the First Step towards Ending Confederate Myths." National Geographic (July 2). https://www.nationalgeographic.com/ history/2020/07/toppling-statues-is-first-step-towardending-confederate-myths/

Dunbar-Ortiz, Roxanne and Gilio-Whitaker Dina, 2016. "All the Real Indians Died Off" and 20 Other Myths About Native Americans. Boston: Beacon Press.

Elgersman Lee, Maureen, 1999. Unyielding Spirits: Black Women and Slavery in Early Canada and Jamaica. New York: Garland.

Farrar, Martin, 2020. "Who was Edward Colston and why was his Bristol statue toppled?" The Guardian, June 8, 2020. https://www.theguardian.com/uk-news/2020/ jun/08/who-was-edward-colston-and-why-was-his-bristol-statue-toppled-slave-trader-black-lives-matter-protest

Garneau, David, 2019. "Extra-Rational Indigenous Performance: Dear John; Louis Riel." Canadian Theatre Review 178, (Spring): 72-76.

Hochschild, Adam, 1998. King Leopold's Ghost: A Story of Greed Terror and Heroism in Colonial Africa. Basingstoke, UK: Pan McMillan.

Johns, Christopher M. S. 1998. Antonio Canova and the Politics of Patronage in Revolutionary and Napoleonic Europe. Berkeley: University of California Press.

MacDonald, David, 2020. "Canada needs to reckon with the relics of its colonial past including racist statues." The Conversation, (June 24, 2020). https:// theconversation.com/canada-needs-to-reckon-with-therelics-of-its-colonial-past-including-racist-statues140675

Marsh, James, 2015. "Eugenics Pseudo-Science Based on Crude Misconceptions of Heredity." The Canadian Encyclopedia. https://www.thecanadianencyclopedia.ca/ en/article/eugenics-keeping-canada-sane-feature
McKittrick, Katherine, 2006. Demonic Grounds Black Women and the Cartographies of Struggle. Minneapolis: University of Minnesota Press.

Nelson, Charmaine A. 2007. The Color of Stone: Sculpting the Black Female Subject in Nineteenth-Century America. Minneapolis: University of Minnesota Press.

Nelson, Charmaine, 2017. "Racist monuments don't belong in public but they could be in a museum." Huffington Post, September 28, 2017. https://www.huffingtonpost.ca/charmaine-nelson/racist-monuments-dont-belong-in-public-but-they-could-in-amuseum_a_23224080/

Newsinger, John, 2016. "Why Rhodes Must Fall.” Race and Class 58, no. 2: 70-78.

Platt, Verity, 2020. "Why People Are Toppling Monuments to Racism," Scientific American, June 3, 2020. https://www.scientificamerican.com/article/why-peopleare-toppling-monuments-to-racism/

Rannard, Georgina, 2020. "Leopold II: Belgium Wakes Up to Its Bloody Colonial Past," BBC News. https:// www.bbc.com/news/world-europe-53017188

Rayburn, Alan, and Carolyn Harris, 2015 (2006). "Queen Victoria." The Canadian Encyclopedia. https://www.thecanadianencyclopedia.ca/en/article/victoria

Rudin, Ronald, 2021. "How Montreal Should Repurpose the Monument to Macdonald." Montreal Gazette, January 8, 2021. https://montrealgazette.com/opinion/ opinion-how-montreal-should-repurpose-the-monument-to-macdonald

Selvin, Claire, and Tessa Solomon, 2020. "Toppled and Removed Monuments: A Continually Updated Guide to Statues and the Black Lives Matter Protests." ARTnews, June 11, 2020. https://www.artnews.com/art-news/ news/monuments-black-lives-matter-guide-1202690845

Shepherd, Mpofu, 2017. "Disruption as a Communicative Strategy: The Case of \#FeesMustFall and \#RhodesMustFall students' protest in South Africa." Journal of African Media Studies 9, no. 2: 351-373.

Shohat, Ella, and Robert Stam, 1994. Unthinking Eurocentrism: Multiculturalism and the Media. London: Routledge. 
Stanley, Timothy J., 2016. "John A. Macdonald, 'the Chinese' and Racist State Formation in Canada." Journal of Critical Race Inquiry 3, no. 1: 6-34.

Togoh, Isabel, 2020. "A Toppled Statue of Slave Trader Sparked Global Protests, Now A Monument To Black Lives Matter Occupies That Plinth," Forbes: July 15, 2020. https://www.forbes.com/sites/isabeltogoh/ 2020/07/15/a-toppled-statue-of-slave-trader-sparkedglobal-protests-now-a-monument-to-black-lives-matteroccupies-that-plinth/\#22ca39544619

Yun, Tom, 2018. "Where Sir John A. Macdonald Stands in Canada: An Interactive Map." Macleans, August 19, 2018. https:/www.macleans.ca/news/canada/where-sirjohn-a-macdonald-stands-in-canada-an-interactive-map/ 